\title{
Pemetaan Potensi Batuan Kapur Menggunakan Citra Satelit Landsat 8 di Kabupaten Tuban
}

\author{
Dhiyaulhaq Al Majid dan Bangun Muljo Sukojo \\ Departemen Teknik Geomatika, Fakultas Teknik Sipil dan Perencanaan, Institut Teknologi Sepuluh \\ Nopember (ITS) \\ e-mail: bangunms@gmail.com
}

\begin{abstract}
Abstrak-Indonesia merupakan negara yang kaya akan barang tambang, baik bahan mineral dan logam. Batu kapur (limestone) merupakan salah satu bahan galian industri non logam yang sangat besar potensinya dan tersebar hampir di seluruh wilayah Indonesia. Kabupaten Tuban merupakan salah satu Kabupaten yang berada dipesisir pantai utara Pulau Jawa, tepatnya di Jawa Timur. Sebagai daerah yang berada dalam cekungan Jawa Timur bagian utara dan dimungkinkan sebagai wilayah potensial terdapatnya berbagai sumberdaya mineral, salah satunya adalah batuan gamping atau batuan kapur. Terdapatnya potensi batuan kapur di Kabupaten Tuban tersebut sangat memungkinkan untuk dikelola dan diolah untuk menjadi sebuah industri. Apalagi masih banyaknya sumber batuan gamping yang belum di eksplorasi, Dengan kemajuan teknologi dibidang inderaja, perhitungan estimasi potensi batu kapur dapat dilakukan dengan menggunakan data penginderaan jauh dan sistem informasi geografis. Data penginderaan jauh yang digunakan adalah data citra satelit Landsat 8. Penelitian ini bertujuan untuk mengetahui potensi batuan kapur di Kabupaten Tuban. Parameter yang digunakan untuk identifikasi potensi batu kapur pada penelitian ini ada 4 yaitu tutupan lahan, suhu permukaan, indeks vegetasi, dan unsur geologi. Hasil yang didapatkan dari penelitian ini adalah peta potensi batuan kapur Kabupaten Tuban yang dibagi kedalam 5 kelas yakni potensi sangat rendah, potensi rendah, potensi sedang, potensi tinggi, dan potensi sangat tinggi. Dari pengolahan data dihasilkan di Kabupaten Tuban didominasi oleh tingkat potensi sedang dengan luas 64514,36 hektar sedangkan untuk tingkat potensi tinngi dan sangat tinggi memiliki luas 33511,54 hektar dan 32709,36 hektar.
\end{abstract}

Kata Kunci-Batu Kapur, Kabupaten Tuban, Penginderaan Jauh, Sistem Informasi Geografis.

\section{PENDAHULUAN}

$I^{1}$ NDONESIA merupakan negara yang kaya akan barang tambang, baik bahan mineral dan logam. Berbagai daerah di Indonesia memiliki sumber daya mineral berupa berbagai jenis bahan tambang/galian. Batu kapur (limestone) merupakan salah satu bahan galian industri non logam yang sangat besar potensinya dan tersebar hampir di seluruh wilayah Indonesia (Shubri dan Armin, 2014) [1]. Sebagian besar kandungan batuan ini di Indonesia terdapat di Sumatera Barat, Jawa Timur, Kalimantan Tengah dan Kalimantan Timur. Salah satu daerah yang penghasil utama batu kapur di Jawa Timur, adalah Kabupaten Tuban.

Kabupaten Tuban merupakan salah satu Kabupaten yang berada dipesisir pantai utara Pulau Jawa, tepatnya di Jawa
Timur, berbatasan langsung dengan Kabupaten Lamongan, di sebelah timur, Kabupaten Bojonegoro, di sebelah selatan dan Kabupaten Blora dan Kabupaten Rembang, Jawa Tengah, di sebelah Barat. Sebagai daerah yang berada dalam cekungan Jawa Timur bagian utara dan dimungkinkan sebagai wilayah potensial terdapatnya berbagai sumberdaya mineral, salah satunya adalah batuan gamping atau batuan kapur. Bahan galian tambang batu kapur (limestone) di Kabupaten Tuban tersebar terletak di beberapa lokasi diantaranya di Kecamatan Kerek, Merakurak, Tambakboyo, Palang, Semanding dan Montong.

Ekspolorasi tambang adalah suatu kegiatan untuk mencari titik-titik lokasi dimana suatu daerah bisa ditambang serta daerah tersebut masih bernilai ekonomis,untuk ditambang. Salah satu hal yang terpenting dalam pekerjaan pertambangan adalah perhitungan estimasi potensi tambang. Estimasi potensi tambang berperan penting dalam menentukan jumlah kualitas, kerja produksi, cara penambangan yang dilakukan, bahkan memperkirakan waktu yang dibutuhkan untuk melakukan usaha penambangan.

Dengan kemajuan teknologi dibidang inderaja, perhitungan estimasi potensi batu kapur dapat dilakukan dengan menggunakan data citra satelit Landsat 8 dan sistem informasi geografis. Penelitian ini diharapkan nantinya bisa dijadikan sebagai data spasial dengan metode yang lebih cepat dan efisien dalam perhitungan estimasi potensi batuan kapur.

\section{METODOLOGI PENELITIAN}

\section{A. Lokasi Penelitian}

Lokasi penelitian studi ini dilakukan di Kabupaten Tuban, Jawa Timur. Secara geografis terletak pada koordinat $111^{\circ} 30^{\prime}$ - $112^{\circ} 35 \mathrm{BT}$ dan $6^{\circ} 40^{\prime}-7^{\circ} 18^{\prime} \mathrm{LS}$. 


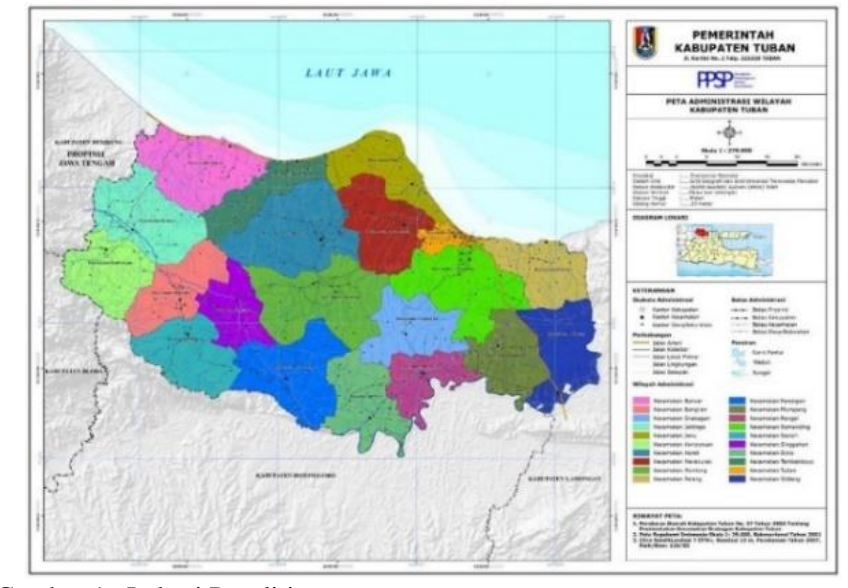

Gambar 1. Lokasi Penelitian

B. Data dan Peralatan

1) Data

Data yang digunakan dalam penelitian studi ini antara lain:

- Citra Landsat 8 tanggal akuisisi 24 September 2014 path/row 119/065 dengan resolusi $30 \mathrm{~m}$ (sumber: http://earthexplorer.usgs.gov)

- Peta Geologi Kabupaten Tuban tahun 2008 (sumber: Bappeda Tuban)

- Peta batas administrasi (sumber: Peta RBI 1:25000)

\section{2) Peralatan}

Peralatan yang digunakan dalam penelitian ini meliputi:

a. Perangkat Keras

- GPS handheld

- Laptop

b. Perangkat Lunak

- Perangkat lunak pengolah citra satelit,

- Perangkat lunak pengolahan data geospasial

- Perangkat lunak pengolah data GPS

- Microsoft Office 2016

\section{Tahap Pengolahan Data}

Penelitian ini dilakukan dengan melalui beberapa tahapan pengolahan data.

a. Pengolahan Citra Satelit Landsat 8

Melakukan koreksi geometrik untuk penempatan kembali posisi pixel ke tempat yang sudah dianggap benar, selanjutnya pemotongan (cropping) untuk mendapatkan citra yang hanya meliputi daerah penelitian yaitu Kabupaten Tuban, Jawa Timur dan koreksi radiometrik untuk merperbaiki visual citra.

b. Pembuatan Peta Tutupan Lahan

Pembuatan peta dilakukan dengan menggunakan supervised classification : maximum likelihood, serta menghitung matriks konfusi dan melakukan pengharkatan.

c. Pembuatan Peta Suhu Permukaan

Pembuatan peta dilakukan dengan menggunakan algoritma

Land Surface Temperature (LST), serta dilakukan klasifikasi dan pegharkatan

d. Pembuatan Peta Indeks Vegetasi

Pembuatan peta dilakukan dengan menggunakan algoritma
NDVI, serta dilakukan klasifikasi dan pengharkatan.

e. Pembuatan Peta Geologi

Data unsur Geologi didapatkan dalam format shapefile kemudian dilakukan pengharkatan pada data yang tersedia..

f. Uji ketelitian

Dilakukan dengan Ground truth pada peta tutupan lahan dan peta suhu permukaan. Uji ketelitian dilakukan untuk melakukan pengecekan antara hasil pengolahan citra dengan data pengukuran di lapangan.

g. Overlay dan Reklasifikasi

Dilakukan overlay terhadap empat peta yang telah diberikan harkat yaitu peta tutupan lahan, peta suhu permukaan, peta indeks vegetasi dan peta geologi agar mendapatkan peta potensi batuan kapur. Reklasifakasi dilakukan dengan membagi menjadi 5 kelas potensi batuan kapur.

\section{HASIL ANALISA}

\section{A. Pengolahan Citra Landsat 8}

Citra satelit Landsat 8 yang digunakan adalah path/row: 119/65 dengan tanggal perekeman 24 September 2014. Langkah awal yang dilakukan adalah dengan melakukan koreksi geometrik dengan mengggunakan metode Rektifikasi (image to map) dengan Peta RBI yang dijadikan acuannya. Pada Rektifikasi ini RMSE yang didapatkan adalah 0.25 dengan delapan titik kontrol yang tersebar di daerah penelitian.

Tahap selanjutnya adalah melakukan koreksi radiometrik Koreksi radiometrik teridri dari dua tahap yaitu kalibrasi radiometrik dan koreksi atmosferik. Kalibrasi radiometrik dilakukan dengan mengubah Digital Number (DN) menjadi radiance dan/atau reflectance. Koreksi atmosferik yang dilakukan menggunakan metode FLAASH (Fast Line-of-sight Atmospheric Analysis of Spectral Hypercubes), FLAASH dapat menghilangkan pengaruh gangguan atmosfer dengan memperoleh parameter yang lebih akurat dari reflektivitas, emisivitas, suhu permukaan dan fisik permukaan [2].

Tahap selanjutnya adalah pemotongan citra sesuai daerah penelitian yaitu Kabupaten Tuban dengan menggunakan data batas admistrasi Peta RBI

\section{B. Peta Tutupan Lahan}

Pembuatan peta tutupan lahan menggunakan citra satelit Landsat 8 path/row 119/65 dengan tanggal akuisisi 24 September 2014. Pembuatan peta dilakukan dengan interpretasi digital menggunakan metode Supervised Classification : Maximum Likelihood dan didapatkan nilai matrik konfusi sebesar $88.404 \%$. Sistem klasifikasi pada penelitian ini berdasarkan SNI 7645:2010 Klasifikasi Penutup Lahan [3].

Pada daerah penelitian didapatkan 5 tipe tutupan lahan yaitu permukiman, sawah, badan air, semak belukar, lahan terbuka/tegalan. Hasil klasifikasi tutupan ini perlu dilakukan uji ketelitian di lapangan dengan menggunakan 20 titik sampel dan didapatkan ketelitian sebesar 85\%. Menurut Daels Antrop menyatakan bahwa hasil interpretasi dikatakan baik apabila mempunyai ketelitian $\geq 80 \%$ [4]. Berikut adalah hasil peta tutupan lahan Kabupaten Tuban 


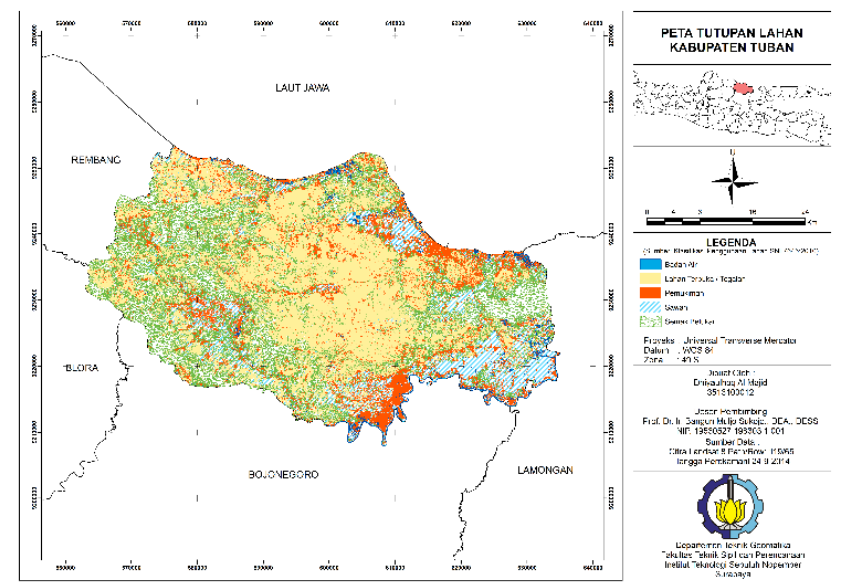

Gambar 2. Peta Tutupan Lahan

Berikut adalah tabel klasifikasi tutupan lahan beserta luasannya.

Tabel 1.

Klasifikasi dan Luas Tutupan Lahan

\begin{tabular}{|c|c|c|}
\hline Kelas & Tutupan Lahan & Luas(ha) \\
\hline 1 & Badan Air & 1574,28 \\
\hline 2 & Lahan Terbuka/Tegalan & 81757,71 \\
\hline 3 & Pemukiman & 36235,89 \\
\hline 4 & Sawah & 33305,94 \\
\hline 5 & Semak Belukar & 44787,51 \\
\hline
\end{tabular}

\section{Peta Suhu Permukaan}

Pembuatan peta suhu permukaan menggunakan citra satelit Landsat 8 path/row 119/65 dengan tanggal akuisisi 24 September 2014. Pembuatan peta dilakukan dengan melakukan perhitungan algoritma LST.

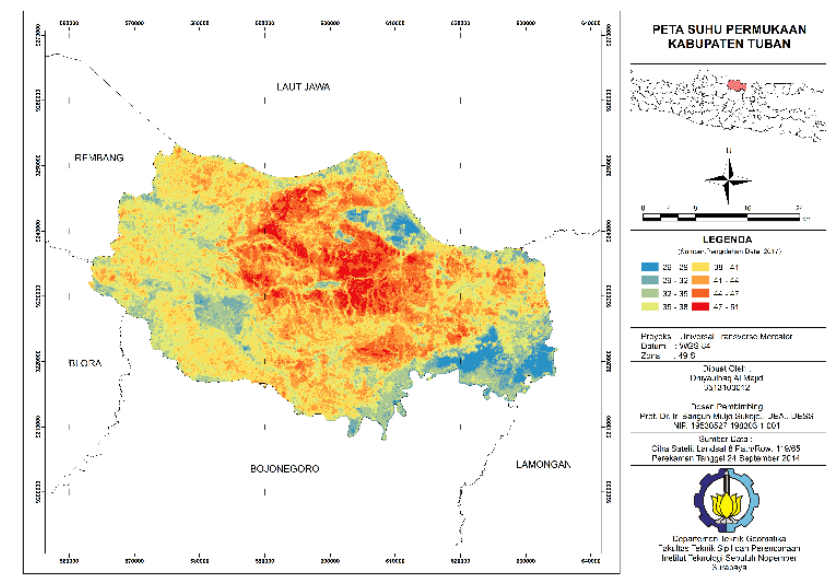

Gambar 3. Peta Suhu Permukaan

Dari perhitungan algoritma LST pada daerah penelitian didapatkan suhu terendah $26^{\circ} \mathrm{C}$ dan suhu tertinggi $51^{\circ} \mathrm{C}$ dan dapat diklasifikasikan menjadi delapan seperti tabel dibawah ini.

Tabel 2.

Klasifikasi Suhu Permukaan

\begin{tabular}{cc}
\hline \hline Kelas & Suhu Permukaan $\left({ }^{\circ} \mathrm{C}\right)$ \\
\hline 1 & $26 \mathrm{~s} / \mathrm{d} 29$ \\
2 & $29 \mathrm{~s} / \mathrm{d} 32$ \\
3 & $32 \mathrm{~s} / \mathrm{d} 35$ \\
4 & $35 \mathrm{~s} / \mathrm{d} 38$ \\
5 & $38 \mathrm{~s} / \mathrm{d} 41$ \\
6 & $41 \mathrm{~s} / \mathrm{d} 44$ \\
\hline
\end{tabular}

\begin{tabular}{ll}
\hline 7 & $44 \mathrm{~s} / \mathrm{d} 47$ \\
8 & $47 \mathrm{~s} / \mathrm{d} 51$ \\
\hline \hline
\end{tabular}

Berdasarkan tabel emisivitas maka suhu permukaan batuan kapur seharusnya adalah $38^{\circ} \mathrm{C}$ [5]. Tetapi pada pengolahan citra suhu pada daerah permukaan batuan kapur sebesar $44^{\circ} \mathrm{C}-48^{\circ} \mathrm{C}$. Hasil suhu permukaan ini tentunya perlu dicek sesuai dengan suhu permukaan di lapangan dengan menggunakan 19 titik sampel. Hasil yang didapatkan adalah sebagai berikut:

Tabel 3.

\begin{tabular}{ccc} 
& Perbandingan Suhu Citra dan Suhu Lapangan \\
\hline \hline Sample & Suhu Citra $\left({ }^{\circ} \mathrm{C}\right)$ & Suhu Lapangan $\left({ }^{\circ} \mathrm{C}\right)$ \\
\hline 1 & 41,20 & 33,5 \\
2 & 45,74 & 33,0 \\
3 & 36,45 & 30,0 \\
4 & 40,30 & 32,5 \\
5 & 43,28 & 30,0 \\
6 & 46,60 & 37,5 \\
7 & 43,70 & 35,0 \\
8 & 37,91 & 35,0 \\
9 & 42,52 & 33,5 \\
10 & 37,27 & 29,0 \\
11 & 42,31 & 34,5 \\
12 & 42,22 & 32,0 \\
13 & 43,48 & 33,0 \\
14 & 38,70 & 32,5 \\
15 & 37,59 & 31,5 \\
16 & 39,43 & 30,5 \\
17 & 38,56 & 31,0 \\
18 & 43,89 & 35,0 \\
19 & 37,07 & 31,0 \\
\hline \hline
\end{tabular}

Sampel suhu lapangan digunakan untuk melakukan uji korelasi. Hal ini dilakukan untuk mengetahui sejauh mana korelasi atau kedekatan suhu permukaan hasil pengolahan citra dengan hasil lapangan. Ketika dilakukan uji korelasi antara suhu permukaan di citra dan lapangan didapatkan nilai 0.64 dapat diartikan bahwa keeratan hubungan antara suhu citra dan suhu di lapangan adalah 64\%. Hasil ini menunjukkan korelasi yang kuat antara suhu citra dan lapangan [6].

Adanya perbedaan antara suhu pada citra dan suhu pada lapangan disebabkan oleh beberapa faktor, salah satunya perbedaan waktu pengambilan data, suhu pada citra diambil pada tanggal 24 September 2014 sedangkan suhu di lapangan diambil pada tanggal 6-7 Mei 2017 dimana bulan September merupakan musim kemarau sedangkan pada bulan Mei merupakan akhir musim hujan. Walaupun akhir musim hujan pada daerah penelitian masih sering turun hujan.

\section{Peta Indeks Vegetasi}

Pembuatan peta indeks vegetasi menggunakan citra satelit Landsat 8 path/row 119/65 dengan tanggal akuisisi 24 September 2014. Pembuatan peta dilakukan dengan melakukan perhitungan algoritma NDVI .

Dari pengolahan NDVI pada daerah penelitian didapatkan nilai terendah -0.909 dan nilai tertinggi 0.921. Semakin rendah nilai NDVI, maka daerah tersebut semakin tinggi potensi adanya batuan kapur, begitu juga sebaliknya ${ }^{[5]}$ Hal ini dikarenakan batuan kapur sering terdapat pada ladang/tegalan. 


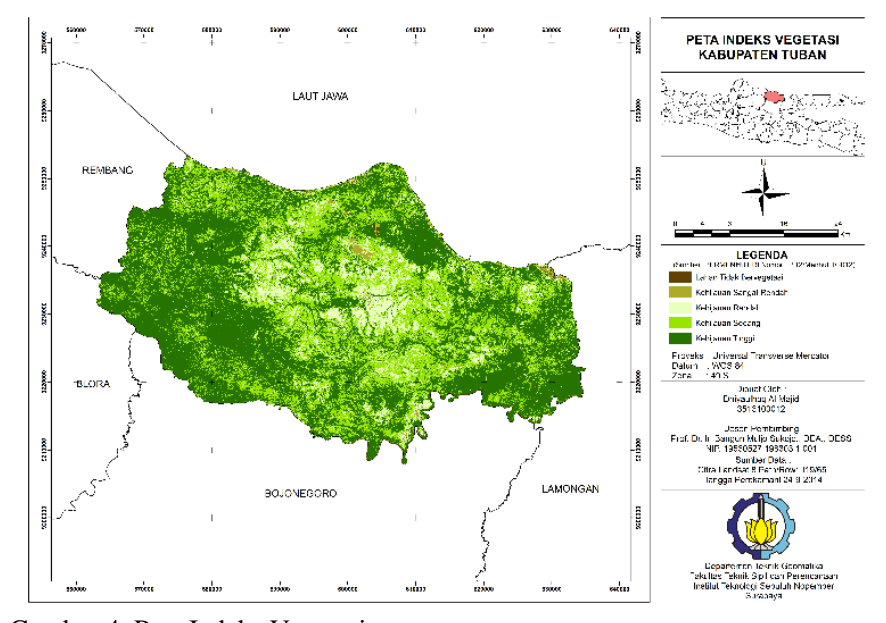

Gambar 4. Peta Indeks Vegetasi

Penentuan kelas indeks vegetasi pada algoritma NDVI mengacu pada Permen No: P.12/Menhut-II/2012 yang membagi menjadi lima kelas klasifikasi [7]. Berikut adalah tabel klasifikasi NDVI beserta luasannya

Tabel 4.

Klasifikasi dan Luas Indeks Vegetasi

\begin{tabular}{cccr}
\hline \hline Kelas & NDVI & Kategori & \multicolumn{1}{c}{ Luas(ha) } \\
\hline 1 & $-0.90 \mathrm{~s} / \mathrm{d}-0.03$ & Lahan tidak bervegetasi & 630,79 \\
2 & $-0.03 \mathrm{~s} / \mathrm{d} 0.15$ & Kehijauan Sangat Rendah & 1948,27 \\
3 & $0.15 \mathrm{~s} / \mathrm{d} 0.25$ & Kehijauan Rendah & 23415,03 \\
4 & $0.25 \mathrm{~s} / \mathrm{d} 0.35$ & Kehijauan Sedang & 64115,48 \\
5 & $0.35 \mathrm{~s} / \mathrm{d} 0.92$ & Kehijauan Tinggi & 107538,92 \\
\hline \hline
\end{tabular}

E. Peta Geologi

Data Geologi didapatkan dalam format shapefile (vektor) yang mencakup Kabupaten Tuban.

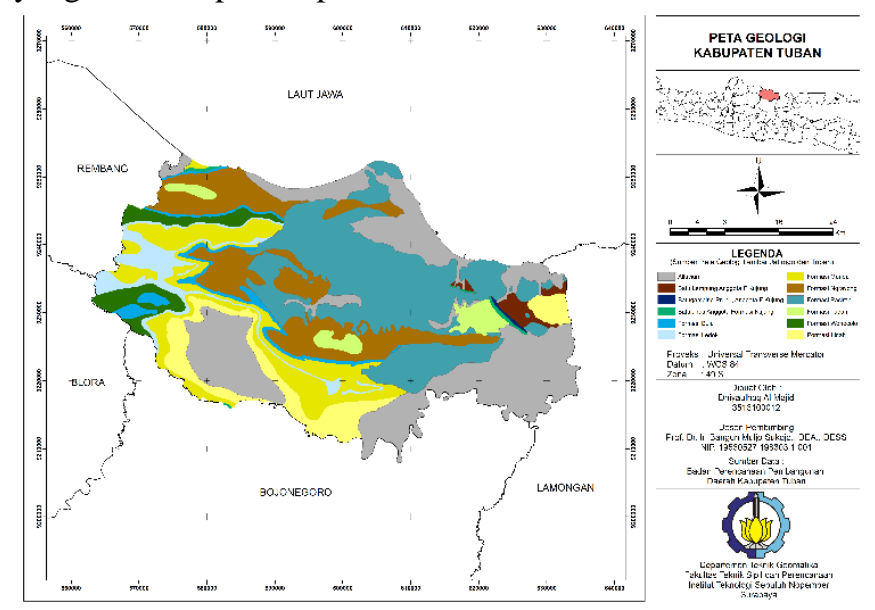

Gambar 5. Peta Geologi

Penentuan klasifikasi dilakukan berdasarkan Peta Geologi [8]. hingga didapatkan hasil sebagai berikut.

\begin{tabular}{llr}
\multicolumn{3}{c}{ Tabel 5. } \\
\hline \multicolumn{3}{c}{ Klasifikasi dan Luas Unsur Geologi } \\
\hline \hline Kelas & \multicolumn{1}{c}{ Batuan Penyusun } \\
\hline 1 & Alluvium & 5253,34 \\
2 & Batu Lempung Anggota F. Kujung & 2292,74 \\
3 & Batugamping Prupu, Anggota F. Kujung & 256,51 \\
& & 710,35 \\
4 & Batulanau Anggota F. Kujung & 5702,07 \\
5 & Formasi Bulu & 8681,16 \\
6 & Formasi Ledok & 22819,35 \\
7 & Formasi Mundu
\end{tabular}

\begin{tabular}{llr}
\hline 8 & Formasi Ngrayong & 27763,94 \\
9 & Formasi Paciran & 51092,50 \\
10 & Formasi Tuban & 5271,39 \\
11 & Formasi Wonocolo & 6939,52 \\
12 & Formasi Lidah & 13612,92 \\
\hline \hline
\end{tabular}

Batu Kapur/Batugamping di daerah Kabupaten Tuban banyak terdapat pada formasi Paciran, Kujung, dan Tuban [8]

\section{F. Peta Potensi Batuan Kapur}

Peta potensi batuan kapur dibuat dengan melakukan overlay terhadap empat peta yaitu peta tutupan lahan, peta suhu permukaan, peta indeks vegetasi dan peta geologi.

Overlay dilakukan dengan menggunakan metode intersect dilanjutkan dengan perhitungan jumlah harkat dan klasifikasi ulang sesuai interval yang ditenntukan dengan rumus sebagai berikut:

$$
\text { interval }=\frac{\text { nilai maksimum-nilai minimum }}{\text { banyak kelas }}
$$

Klasifikasi dibagi ke dalam lima kelas sehingga interval yang didapatkan dari perhitungan adalah 3 seperti gambar berikut.

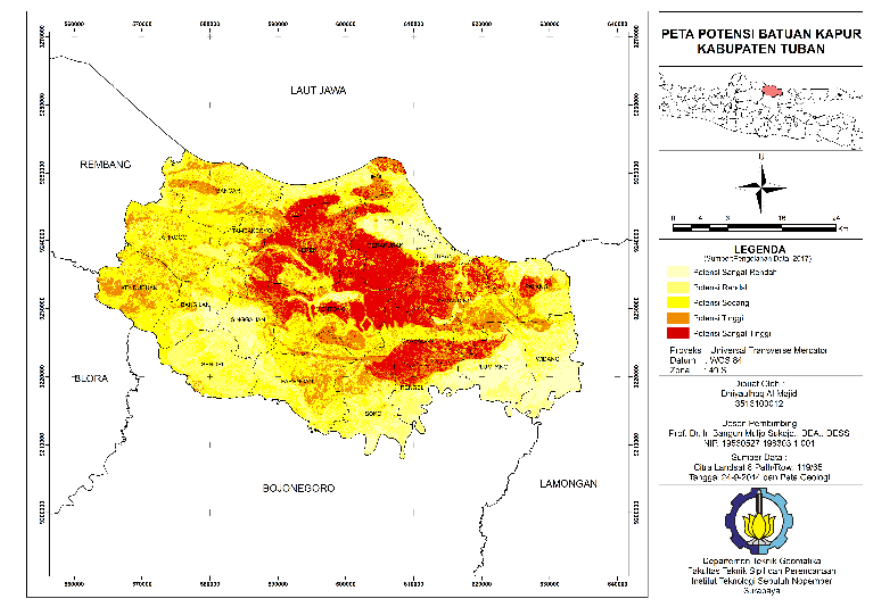

Gambar 6. Potensi Batuan Kapur

Dari hasil klasifikasi didapatkan luas masing-masing kelas potensi batuan kapur seperti tabel berikut.

Tabel 6.

Klasifikasi dan Luas Potensi Batuan Kapur

\begin{tabular}{lcc}
\hline \hline \multicolumn{1}{c}{ Kategori } & Luas (ha) & $\%$ \\
\hline Potensi Sangat Rendah & 20267,90 & 10,29 \\
Potensi Rendah & 45921,29 & 23,32 \\
Potensi Sedang & 64514,36 & 32,76 \\
Potensi Tinggi & 33511,54 & 17,02 \\
Potensi Sangat Tinggi & 32709,36 & 16,61 \\
\hline \hline
\end{tabular}

\section{KESIMPULAN}

Berdasarkan penelitian yang sudah dilakukan dapat disimpulkan:

a. Didapatkan lima kelas potensi batuan kapur yaitu sangat rendah, rendah, sedang, tinggi, dan sangat tinggi.

b. Kabupaten Tuban didominasi oleh tingkat potensi sedang dengan luas 64514,36 ha, sedangkan untuk tingkat potensi sangat rendah 20267,90 ha, potensi rendah 45921,29 ha, potensi tinggi 33511,54 ha dan sangat tinggi 32709,36 ha.

c. Tiga Kecamatan yang memiliki daerah luasan paling besar untuk potensi sangat tinggi adalah Kecamatan Kerek, 
Kecamatan Montong dan Kecamatan Merakurak dengan luasan 7423,00 ha, 5641,67 ha dan 5255,72 ha.

\section{DAFTAR PUSTAKA}

[1] I. Shubri, E. dan Armin, "Penentuan Kualitas Batu Kapur dari Desa Halaban Kabupaten Lima Puluh Kota di Laboratorium Dinas Energi dan Sumber Daya Mineral Provinsi Sumatera Barat," Universitas Bung Hatta, 2014.

[2] L. Fibriawati, "Koreksi Atmosfer Citra SPOT-6 Menggunakan Metode MODTRAN4," 2016.
[3] B. S. Nasional, Klasifikasi Penggunaan Lahan SNI 7645:2010. Jakarta, 2010.

[4] T. Gunawan, "Penginderaan Jauh Terapan Studi Pedesaan," Universitas Gadjah Mada, 1993.

[5] Nurjannah, "Pemodelan Estimasi Potensi Tambang Batu Kapur Dari Hasil Analisa Data Citra Satelit Landsat 7 ETM+ (Studi Kasus: Tambang Batu Kapur PT. Semen Gresik Persero Tbk. Pabrik Tuban)," 2013.

[6] S. Jonathan, "Metode Penelitian Kuantitatif dan Kualitatif," 2006

[7] Peraturan Menteri Kehutanan Republik Indonesia Nomor: P.12/Menhut-Ii/2012. 2012.

[8] H. dan Suharsono, Peta Geologi lembar Tuban, Jawa Timur. 1997. 